\title{
An Analysis of the Relationship between Remuneration (Real Wage) and Labour Productivity in South Africa
}

\author{
Johannes Tshepiso Tsoku \\ Department of Statistics, North West University, Mafikeng Campus, South Africa \\ Email: johannes.tsoku@nwu.ac.za
}

Florance Matarise

Department of Statistics, University of Zimbabwe, Mount Pleasant, Harare, Zimbabwe Email: matarise@science.uz.ac.zw

\section{Doi:10.5901/jesr.2014.v4n6p59}

\begin{abstract}
This study involved analysis of the relationship between remuneration (real wage) and labour productivity in South Africa at the macroeconomic level, using time series and econometric techniques on annual time series data from 1970 to 2011. The variables are tested for stationarity using the Augmented Dickey-Fuller and Phillips Perron are proved to be integrated to order one. Further analysis yields a result which depicts significant evidence of a structural break in 1990 and a long run cointegrating relationship between remuneration, labour productivity and unemployment. The coefficient of the error correction term in the labour productivity is large, indicating a rapid adjustment of labour productivity to equilibrium. However, remuneration does not Granger cause labour productivity and vice versa.
\end{abstract}

Keywords: Remuneration, Labour productivity, Unemployment, Cointegration, Error Correction Model, Vector Auto-Regression, Causality

\section{Introduction}

Remuneration (real wage), rate of unemployment and productivity are important economic indicators or measures in an economy. Productivity measures the output produced by workers in various sectors of the economy while remuneration is the cost of producing that output in the form of salaries and wages. Unemployment is a measure of the number of people in the workforce who are out of work or are without jobs. Numerous economic theories have been put forward justifying a relationship between the above mentioned variables, including bargaining, efficiency wage, search and contract theories (Wakeford, 2004).

There has been an increasing volume of empirical studies regarding the association between labour productivity and remuneration (Goh, 2009). Most of these empirical studies found positive long run relationships between labour productivity and remuneration, although the relationship between labour productivity and remuneration has not been one to one. The studies by Hall (1986), Wakeford (2004), Alexander (1993), Strauss and Wohart (2004) for instance, found positive long run relationships between labour productivity and remunerations in the respective countries which they studied, and the increases in labour productivity are linked with a less than unit increase in remunerations (MacKinnon, 1991).

The marginal productivity theory proposes that exceedingly productive employees are highly remunerated, and less productive employees are less remunerated. At the macroeconomic level, an increase in remuneration is expected to increase the cost of workforce and therefore cause factor substitution from labour to capital. This could increase marginal productivity and, hence, average out labour productivity. Therefore, it is hypothesized that real wages are positively affected by productivity (Goh, 2009). Employees that are highly remunerated are not likely to move from one company to the other. Thus employers can keep more productive and experienced employees than newly employed ones who may not be as productive. Akerlof (1982) also proposed that when companies increase employees' remuneration, they put forth greater efforts out of a sense of loyalty to those employers.

As mentioned before, remuneration, the unemployment rate and labour productivity are significant economic measures in any economy. A rise in remuneration may increase workers' productivity and could lead to an increase in 
unemployment rate. This implies that there is a link between remuneration, the unemployment rate and labour productivity and there is a need to confirm whether the variables are at an equilibrium point. The purpose of this study is to use econometrics and statistical methods described above to determine the relationship between employeeremuneration, labour productivity and unemployment and to determine the directions of causality between the series. In this regard, the study asks the following questions: Is there a long-term relationship (cointegration) between remuneration, labour productivity and unemployment? What are the short-term associations between these variables? Can econometric and/or statistical techniques shed some light on the directions of causality between these variables? What models are obtained for these relationships?

The paper is set out as follows. Section 2 discusses some of literature relating to our study. Section 3 briefly outlines the methodological framework for causality issues and the long run equilibrium relationship among these variables. Section 4 presents the results and discussions. Concluding remarks is given in section 5.

\section{Literature Review}

The relationship between remuneration, unemployment and labour productivity has received ample attention in literature, although a number of different methods have been taken. The purpose of this review is to provide a brief overview of some of these methods/approaches undertaken by different authors.

Erenburg (1998) investigated the long run connection between labour productivity and real wages in the United States (US) from 1948 - 1990 and identified a long run, counter-cyclical relationship between real wages and labour productivity once the empirical stance had controlled for capital stocks. The study by Alexander (1993) examined the relationship between labour productivity, unemployment and wages in the United Kingdom (UK) for the year 1955 - 1991 at a microeconomic level. She found evidence of a structural break in 1979 and as a result split her sample into two sub periods and then applied the cointegrating vector autoregression (VAR) approach developed by Johansen (1988), to test for long term relationships between the variables of interest, and then applied the Granger causality concept in an attempt to establish empirically the causal relations between the three variables.

Hondroyiannis and Papapetrou (1997) and Gneezy and Rustichini (2000) found that the relationship between labour productivity and real wages is not monotonic and that offering higher remuneration does not always encourage labour productivity (Brown et al., 1976). Hall (1986) found that remuneration, unemployment and labour productivity formed a cointegrated system in the UK. Ho and Yap (2001) studied wage formation in the Malaysian manufacturing industry from the year 1975 - 1997 and they found a very significant relationship between labour productivity and wages for the Malaysian manufacturing industry where in the long run the rise in real wage exceeded the increase in labour productivity.

Millea (2002) obtained empirical evidence about the bi-directional relationship between labour productivity and wages, in particular bearing in mind the nature of the wage setting process in different countries. According to Bender and Theodossiou (1999), there is evidence of cointegration between wages and labour productivity for Denmark, Norway, Sweden, the Netherlands and the UK. Cointegration relation also exists among productivity and employment for Canada and the US, while both cointegrating relations apply to Italy. Nevertheless, there is no relationship between employment and wages for the ten Organisations for Economic Co-operation and Development (OECD) countries under study.

The study by Wakeford (2004) found that there exists long run equilibrium between real wages and labour productivity in South Africa, unemployment was apparently not linked to the two variables. In the short run, real wages had a negative impact on labour productivity but not for the reverse case (Hall, 1986; Alexander, 1993 and Wakeford, 2004). Fedderke and Mariotti (2002) alludes that during 1990 there was evidence of a structural break in their analysis at sectorial level. This phenomenon accrued from changes in employment and an accumulating skills intensity of production. Numerous factors may reveal a structural break in or around 1990. Using the Engle and Granger approach, Du Toit and Koekermoer (2003) found a negative long run relationship between the unemployment rate and real wages and a positive connection with labour productivity.

As mentioned before, the marginal productivity theory recommends that highly productive employees are highly compensated, and less productive employees are less highly compensated. Higher productivity in turn could cause remunerations to rise. Therefore, it is hypothesized that labour productivity has a positive impact on remuneration. However, the effect of an increase in labour productivity on unemployment is ambiguous. As labour productivity rises, employees are more efficient (which implies lower demand for labour), hence, the rate of unemployment could increase. Alternatively, an increase in labour productivity could have a positive impact on employment via its contribution to higher 
output (which implies higher demand for labour), thereby decreasing the rate of unemployment, ceteris paribus (Alexander, 1993 and Wakeford, 2004). A rise in labour productivity is a basic source of improvement in remuneration and thus living standards (Du Plooy, 1988).

If wages should increase rapidly, but productivity increases more even more rapidly, then the net impact on the economy would normally be positive. This is because the cost-increasing impact of wages would be neutralised by the productivity increases. The sharp increases in labour productivity were achieved by reducing the work force, which in turn might have been caused by the sharp increases in real wages that took place in earlier years. There might thus be a link between the increases in the real wages in earlier years and the sharp increases in productivity in later years. It should also be taken into account that a wage increase could under certain circumstances lead to an equivalent productivity increase, which is called the efficient wage hypothesis (Barker, 2002).

The efficiency wage theory suggests that wages affect both labour productivity and unemployment. The theory also proposes that the higher the wage level of an employee, the higher the effort level of his employee. This implies that raising the wage level of employees enables them to increase productivity, because employees make a great effort to respond to high incentives provided by employers. Akerlof (1982) argued that increasing wages can stimulate employee exertion and strengthen long term employment relationships. Highly paid employees are less likely to resign or to move from one company to the other. Thus firms can retain more skilled and productive employees than newly-hired workers who may not be as productive as experienced workers. This could also have an impact on unemployment rate. Hence, it is hypothesized that wages positively affect both productivity and unemployment.

The gift-exchange model of Akerlof $(1982,1984)$ argued that a higher wage is seen by employees as a gift from the employer, and they will return this gift in the form of higher effort (being more productive). The fair wage-effort model of Akerlof and Yellen (1990) documented that if employees were compensated a wage below what they perceived as fair, they would not put as much effort as they would if they get a "fair" wage. Therefore, the efficiency wages theory proposes that real wages induce labour productivity rather than the reversal.

In South Africa, some studies have been conducted using different techniques to find the relationship between remuneration (real wages) and labour productivity for different countries. For example, Hall (1983), Ho and Yap (2001), Du Toit and Koekermoer (2003) found the long run relationship between remuneration and labour productivity using Engle and Granger approach while Alexander (1993) and Wakeford (2004) analysed the same relationship using Johansen technique. Using Johansen cointegration technique, this study intends to contribute to the empirical knowledge by analysing the relationship between remuneration and labour productivity in South Africa. The following section deals with the methodology of the paper.

\section{Reseach Methodology}

\subsection{Data source}

The data used here as mentioned is yearly secondary data set from 1970 to 2011 obtained from the World Bank, Statistics South Africa and the South African Reserve Bank (SARB). This paper uses three variables, namely: total remuneration per worker and labour productivity, both pertaining to non-agricultural sector. The third variable is the total, economy wide rate of unemployment, calculated according to the broad definition. All variables used in this study were transformed in logarithmic form so that coefficients can be interpreted as elasticities and are unit free. Eviews software package will be used to do necessary analysis of the study.

\subsection{Cointegration analysis}

Several macroeconomic time series contain unit roots dominated by stochastic trends as developed by Nelson and Plosser (1982). The first step is to test for unit roots using Augmented Dickey Fuller (ADF) $(1979,1981)$ and the PhillipsPerron (PP) (1988) tests. If the series is nonstationary and its first difference is stationary, then the series contains a unit root. The second step is to test for cointegration among variables using the Johansen's (1991) technique. Initially obtain a VAR model then apply the Johansen technique, involves the identification of rank of the $n \times n$ matrix $\Pi$ in the specification given by:

$$
\Delta X_{t}=\delta+\sum_{i=1}^{k-1} \Gamma_{i} \Delta X_{t-i}+\prod X_{t-k}+\varepsilon_{t}
$$

where $X_{t}$ is a column vector of the $n$ variables, $\Delta$ is the difference operator, $\Gamma$ and $\Pi$ are the coefficient 
matrices, $k$ denotes the lag length and $\delta$ is a constant. In the absence of cointegrating vector, $\Pi$ is a singular matrix, which means that the cointegrating vector rank is equal to zero. Then again, in a cointegrated scenario, the rank of $\Pi$ could be anywhere between zero and $n$. In other words, the Johansen cointegration test can determine the number of cointegrating equation and this number is named the cointegrating rank. If $0<\mathrm{r}<\mathrm{n}$ then there are $n \times r$ matrices of a $\alpha$ and $\beta$ such that:

$$
\Pi=\alpha \beta^{\prime}
$$

where $\beta$ is cointegrating vector; hence, $\beta^{\prime} X_{t}$ is $I(0)$ although $X_{t}$ are $I(1)$ and the strength of cointegration relationship is measured by $\alpha$ 's. in this framework, $\left(A_{0}, A_{1}, \ldots, A_{p-1}, \Pi, \Omega\right)$ are estimated through maximum likelihood procedures, such that " $\Pi^{\prime \prime}$ can be written as in (2). To estimate these parameters, the two step procedures must be followed. In the first step, regress $\Delta X_{t}$ on $\Delta X_{t-1}, \ldots, \Delta X_{t-p+1}$ and obtain the residuals $\hat{\mu}_{t}$. In the second step, regress $X_{t-1}$ on $\Delta X_{t-1}, \Delta X_{t-2} \ldots, \Delta X_{t-p+1}$ and obtain the residuals $\hat{e}_{t}$.

The Johansen Maximum likelihood test provides a test for the rank of $\Pi$, namely the trace test $\lambda_{\text {trace }}$ and the maximum eigenvalue test $\lambda_{\max }$. The first step is to obtain the $\lambda_{\text {trace }}$ statistic which tests whether the number of cointegrating vector is zero or one. The next step is to obtain, the $\lambda_{\max }$ statistic which tests whether a single cointegration equation is sufficient. The null hypothesis $\mathrm{H}_{0}$ test that $r=h, 0 \leq h<n$ against the alternative $\mathrm{H}_{1}$ which tests that $r=n$ by obtaining the following statistics:

$$
\lambda_{\text {trace }}(r)=-T \sum_{i=r+1}^{n} \ln \left(1-\hat{\lambda}_{i}\right),
$$

where $\hat{\lambda}_{r+1}, \hat{\lambda}_{n}$ are the estimated $n-r$ smaller eigenvalues. Equation (3) follows $\chi^{2}$ distribution and called as trace statistics. Furthermore, the null hypothesis to be tested is that there are at the most $r$ cointegrating vectors. That is, the number of cointegrating vectors is less than or equal to $r$, where $r$ is $0,1,2 \ldots$ and so forth. In each case, the null hypothesis is tested against the alternative.

Alternatively, the L-max statistic is:

$$
\lambda_{\max }(r, r+1)=-T \ln \left(1-\hat{\lambda}_{r+1}\right)
$$

In this test, the null hypothesis $\mathrm{H}_{0}$ of $r$ cointegrating vectors is tested against the alternative hypothesis $\mathrm{H}_{1}$, of $r+1$ cointegrating vectors. Thus, the hypothesis $r=0$ is tested against the alternative that $r=1, r=1$ against alternative $r=2$ and so forth.

The third and final step in this study involves a Granger causality test to investigate the casual relationship between the variables of interest. If the economic time series is found to be cointegrated, an econometric framework for an Error Correction Model (ECM) representation can be stated. The ECM procedure can reconcile the long run equilibrium with disequilibrium behaviour in the short run, which allows testing for short term or dynamic causality. According to this approach, "If $X$ and $Y$ are two jointly covariance stationary processes, then $X$ is said to Granger cause $Y$ if past $Y$ and past $X$ better predicts current $Y$ than past $Y$ alone" (Alexander, 1993).

The ECM specification can be written as follows:

$$
\begin{aligned}
& \triangle L_{-} R E M U N_{t}=a_{0}-a_{1} E C T_{t-1}+\sum_{j=1}^{p} a_{2 j} \Delta L_{-} L A B P R O D_{t-j}+\sum_{j=1}^{p} a_{3 j} \Delta L_{-} R E M U N_{t-j}+\varepsilon_{t} \\
& \Delta L_{-} L A B P R O D_{t}=b_{0}-b_{1} E C T_{t-1}+\sum_{j=1}^{p} b_{2 j} \Delta L_{-} L A B P R O D_{t-j}+\sum_{j=1}^{p} b_{3 j} \Delta L_{-} R_{-} E M U N_{t-j}+\mu_{t}
\end{aligned}
$$

where L_REMUNt is logged total remuneration, L_LABPRODt is logged total labour productivity, $\Delta$ is the first-order differencing operator and ECTt-1 stands for the preceding period's error correlation term generated from a cointegrating equation using ordinary least squares (OLS) estimator.

\section{Results and Discussion}

\subsection{Preliminary Data Analysis}

The initial step in this analysis is to perform preliminary relationship tests. The correlation coefficients presented in table 1 below provide an initial indication of the relationships among the three variables. 
Table 1: Correlations

\begin{tabular}{|c|c|c|c|}
\hline & L_REMUN & L_LABPROD & L_UNEMP \\
\hline L_REMUN & 1 & 0.661371546 & 0.846130966 \\
\hline L_LABPROD & 0.661371546 & 1 & 0.890650781 \\
\hline L_UNEMP & 0.846130966 & 0.890650781 & 1 \\
\hline
\end{tabular}

The correlation coefficients presented in Table 1 above give a more precise summary of the relationships among remuneration, labour productivity and unemployment. The correlation coefficient ranges from 0.7 to 0.9 . This means that the pairwise correlations are all strongly positive. It can be concluded that there is a strong positive correlation among all the variables. When productivity increases, employees' contribution to the firms' revenue also increases causing demand for workers to increase. As remunerations are determined by supply and demand, an increase in demand will lead to an increase in remunerations. The next step is to test for structural break using Chow's test and the results are presented in table 2 below.

Table 2: Test for structural break

\begin{tabular}{|l|c|cc|}
\hline F-statistic & 2.570102 & Prob. F(3,36) & 0.0694 \\
\hline Log likelihood ratio & 8.150727 & Prob. Chi-Square(3) & 0.0430 \\
Wald Statistic & 7.710305 & Prob. Chi-Square(3) & 0.0524 \\
\hline \multicolumn{2}{|l}{ Chow Breakpoint Test: 1990, Equation Sample: $1970-2011$} \\
\hline
\end{tabular}

The Chow test shows that there is an evidence of a structural break on the year 1990. The probability value of Log likelihood ratio and Wald statistics is significant at the 5\% level of significance while the F-statistics is significant at $10 \%$. The break could be caused by the state of the economy around the year 1990 when South Africa experienced a severe recession.

\subsection{The Cointegration Results}

As discussed in the methodology section, before applying cointegration techniques the stationarity properties of the series (in logged form) must be analysed. Here we use both the ADF and the PP test for examining the order of integration of the variables. The unit root tests are presented in table 3 below.

Table 3: Unit root tests

\begin{tabular}{|c|cc|cc|}
\hline \multirow{2}{*}{ Variable } & \multicolumn{2}{|c|}{ ADF } & \multicolumn{2}{c|}{ PP } \\
\cline { 2 - 5 } & Level & 1st Difference & Level & 1st Difference $^{\text {st }}$ \\
\hline L_REMUN & 3.269 & $-3.223^{* * *}$ & 5.030 & $-3.295^{* * *}$ \\
L_LABPROD & -3.048 & $-3.631^{* *}$ & -1.975 & $-3.601^{* *}$ \\
L_UNEMP & -2.259 & $-6.853^{*}$ & -2.259 & $-6.853^{*}$ \\
\hline
\end{tabular}

Note: ${ }^{*}{ }^{* *}$, and ${ }^{* *}$ indicates the MacKinnon critical values for ADF and PP at $1 \%, 5 \%$ and $10 \%$ levels are $-4.253,-3.548$, and -3.207 respectively

The results in Table 3 show that all the three variables are stationary at their first differences confirming that the presence of stochastic trends. As the variables follow the same order of integration, $I(1)$, now the study can turn to cointegration in which the long run equilibrium among the variables can be examined. The next step is to apply the Johansen cointegration test to test for the existence of a long run (cointegrating) relationship between L_LABPROD, L_REMUN and L_UNEMP. Results in table 2 shows that there is a significant evidence of structural break in 1990; therefore the study will follow Maddala and Kim (1998) methodology which allows for structural breaks in the first instance. Their methodology involves estimating a VAR and testing for lag order, determining the number of cointegrating vectors using the Johansen procedure, and then estimating error correction models if a cointegrating relation is found. Throughout this process, a dummy variable (D90) is used to test for the presence of a structural break in the year 1990. 
Table 4: Testing for lag order in the VAR

Test statistic and choice criteria for selecting the order of the VAR model

\begin{tabular}{|c|cccccc|}
\hline Lag & LogL & LR & FPE & AIC & SIC & HQ \\
\hline 0 & -402.9770 & NA & 800945.4 & 22.10686 & 22.36809 & 22.19896 \\
1 & -249.9351 & 264.7211 & 334.3452 & 14.32081 & $14.97389^{*}$ & 14.55105 \\
2 & -238.6098 & 17.75320 & 299.5537 & 14.19512 & 15.24004 & 14.56351 \\
3 & -229.0673 & 13.41108 & 301.1764 & 14.16580 & 15.60256 & 14.67232 \\
4 & -204.8671 & $30.08665^{*}$ & $141.0708^{*}$ & $13.34417^{*}$ & 15.17278 & $13.98884^{*}$ \\
5 & -196.7091 & 8.819519 & 163.8656 & 13.38968 & 15.61013 & 14.17249 \\
\hline \multicolumn{5}{l}{ Sample: $1970-2011$, Exogenous variables: C D90, LR: sequential modified LR test statistic (each test at 5\% level), FPE: Final } \\
prediction error, AIC: Akaike information criterion, SIC: Schwarz information criterion, HQ: Hannan-Quinn information criterion \\
\hline
\end{tabular}

Note: * indicates lag order selected by the criterion

The results displayed in table 4 clearly indicate that a VAR(4) is most appropriate. The LR test, FPE, AIC and HQ all selected $p$ equal to four. The tests indicate that one should reject the restriction that lags four should be excluded. With the VAR order having been established, Johansen's (1988) maximum likelihood test for cointegration can be applied.

\subsubsection{Cointegration test for L_REMUN, L_LABPROD and L_UNEMP, 1970 - 2011}

Table 5: Unrestricted Cointegration Rank Test (Trace)

\begin{tabular}{|c|ccc|}
\hline Hypothesized No. of CE(s) & Eigenvalue & Trace Statistic & Prob. $^{* *}$ \\
\hline None $^{*}$ & 0.524870 & 52.61027 & 0.0000 \\
At most 1 * & 0.309539 & 25.07606 & 0.0013 \\
At most 2 * & 0.264596 & 11.37140 & 0.0007 \\
\hline
\end{tabular}

Note: Trace test indicates 3 cointegrating eqn(s) at the 0.05 level

* denotes rejection of the hypothesis at the 0.05 level

**MacKinnon-Haug-Michelis (1999) p-values

Table 6: Unrestricted Cointegration Rank Test (Maximum Eigenvalue)

\begin{tabular}{|c|ccc|}
\hline Hypothesized No. of CE(s) & Eigenvalue & Max-Eigen Statistic & Prob. $^{\text {** }}$ \\
\hline None $^{*}$ & 0.524870 & 27.53421 & 0.0055 \\
At most 1 & 0.309539 & 13.70466 & 0.0611 \\
At most 2 & 0.264596 & 11.37140 & 0.0007 \\
\hline
\end{tabular}

Note: Max-eigenvalue test indicates 1 cointegrating eqn(s) at the 0.05 level

* denotes rejection of the hypothesis at the 0.05 level

**MacKinnon-Haug-Michelis (1999) p-values

The trace test in table 5 indicates that there are three cointegrating vectors while max-eigenvalue test in table 6 indicates one cointegration vector. According to Banerjee et al (1993), in a case where there is a different value of the two tests, the results obtained from the Maximal Eigenvalue of the Stochastic Matrix are preferred (Banerjee et al., 1993) implying that it is concluded that there is one cointegrating equation. This gives an allowance to estimate the long term relationship and ECMs. The long term equilibrium vector is estimated to be $Z=L$ REMUN $+2.47 \mathrm{~L}$ LABPROD -1.257 $L$ UNEMP. The coefficient of $L$ LABPROD has a standard error of 2.17 and is therefore insignificant and the coefficient of L_UNEMP has a standard error of 3.2 and is clearly insignificant ${ }^{1}$. It is therefore not possible to conclude that a long term relationship exists among these three series for this sample period.

${ }^{1}$ Results for the long run coefficient are available from the author on request. 
4.2.2 Cointegration test for L_REMUN, L_LABPROD and L_UNEMP, 1990-2011

Table 7: Unrestricted Cointegration Rank Test (Trace and Maximum Eigenvalue)

\begin{tabular}{|c|ccccc|}
\hline Hypothesized No. of CE(s) & Eigenvalue & Trace Statistic & Prob. $^{* *}$ & Max-Eigen Statistic & Prob. $^{* *}$ \\
\hline None $^{*}$ & 0.740687 & 39.92489 & 0.0025 & 26.99441 & 0.0067 \\
At most 1 $_{\text {At most 2 * }}$ & 0.346209 & 12.93048 & 0.1174 & 8.499350 & 0.3302 \\
& 0.198729 & 4.431130 & 0.0353 & 4.431130 & 0.0353 \\
\hline
\end{tabular}

Note: Trace test indicates 1 cointegrating eqn(s) at the 0.05 level

Max-eigenvalue test indicates 1 cointegrating eqn(s) at the 0.05 level

* denotes rejection of the hypothesis at the 0.05 level

**MacKinnon-Haug-Michelis (1999) p-values

In the 'unrestricted intercepts, no trends' case, the trace test and max-eigenvalue tests indicate that there is one cointegrating vector. The probability value of 0.33 for "at most one" is greater than five percent level of significance. The hypothesis relating to "at most one" cannot be rejected, which means that there is a single cointegrating vector. The long term equilibrium vector is estimated to be $Z=L_{-} R E M U N+2.53$ L_LABPROD -8.83 L_UNEMP. The coefficient of $L_{-} L A B P R O D$ has a standard error of 0.54 and is therefore significant and the coefficient of $L_{-}$UNEMP has a standard error of 1.18 and is therefore significant.

\subsection{Error Correction Results}

As a cointegrating relationship was found between L_REMUN, L_LABPROD and L_UNEMP for the period 1990 to 2011, it may be concluded that there is a long run relationship between the variables but in the short run they might drift apart. The residuals from the long run relationship are used to estimate the short term/run adjustment. The table 10 below gives the summary of the ECMs.

Table 10: Error correction models for L_REMUN and L_LABPROD, 1990-2011

\begin{tabular}{|l|cc|}
\hline \multirow{2}{*}{ Regressor } & \multicolumn{2}{|c|}{ Dependent Variable } \\
\cline { 2 - 3 } & L_REMUN & L_LABPROD \\
\hline \multirow{2}{*}{ Constant } & & $\begin{array}{c}17.32^{* *} \\
(9.21)\end{array}$ \\
\hline \multirow{2}{*}{ ECM(-1) } & $-0.18^{*}$ & $-0.58^{*}$ \\
& $(0.08)$ & $(0.08)$ \\
\hline \multirow{2}{*}{ L_LABPROD(-4) } & -0.39 \\
\hline \multirow{2}{*}{ LL_LABPROD(-5) } & $(0.29)$ & \\
\hline \multirow{2}{*}{ L_REMUN(-1) } & 0.026 & $0.94^{*}$ \\
& $(0.27)$ & $(0.34)$ \\
\hline \multirow{2}{*}{ LL_REMUN(-2) } & & -0.41 \\
& & $(0.34)$ \\
\hline R-squared & $1.47^{*}$ & 0.77 \\
Adjusted R-squared & $(0.1)$ & 0.73 \\
S.E. of regression & 0.99 & 4.65 \\
\hline
\end{tabular}

Note: *significant at 5 percent and ${ }^{\star \star}$ significant at 10 percent. Parentheses indicate standard errors

The ECM term is negative as expected, indicating that remuneration adjusts back towards equilibrium (with productivity) following a shock in the previous year. The magnitude of this coefficients suggest that approximately 0.18 and 0.58 of the disequilibrium is corrected for L_REMUN and L_LABPROD respectively. The coefficient of the error correction term in the $L_{-} L A B P R O D$ is large, indicating a rapid adjustment of labour productivity to equilibrium. For the $L_{-} R E M U N$ model, none of the lagged labour productivity is significant which means that labour productivity has no impact on remuneration in the short term. 


\subsection{Granger Causality Test}

Table 11: Causality between Labour productivity and Remuneration

\begin{tabular}{|l|ccc|}
\hline Null Hypothesis: & Obs & F-Statistic & Prob. \\
\hline L_LABPROD does not Granger Cause L_REMUN & 17 & 0.92822 & 0.5225 \\
L_REMUN does not Granger Cause L_LABPROD & & 1.35422 & 0.3573 \\
\hline
\end{tabular}

The table above gives the result of causality between labour productivity and remuneration. The probability 0.5225 is more than the 5 percent level of significance therefore the null hypothesis is not rejected. This implies that L LABPROD does not Granger causes L_REMUN and the alternative hypothesis is also not rejected, meaning that L_REMUN does not Granger cause L_LABPROD.

\section{Conclusions}

The long run equilibrium relationship between remuneration and labour productivity in South Africa is found in this study using annual time series data from 1970 to 2011. Unemployment does not form part of the cointegrating relationship between remuneration and labour productivity. The study tested for structural break and it is detected in 1990. This research paper also employed ADF and PP tests to investigate the stationarity and it was found that variables are nonstationary at level but stationary at first difference. On application of the Johansen cointegration technique, cointegration is detected between remuneration and labour productivity for this period 1990 to 2011. The coefficient of the error correction term in the labour productivity is large, indicating a rapid adjustment of labour productivity to equilibrium but this labour productivity does not seem to have any impact on remuneration in the short term.

The findings of this study are comparable to previous studies conducted using similar variables. For example, the study by Hall (1983), Wakeford (2004), Du Toit and Koekermoer (2003), Bender and Theodossiou (1999) and Ho and Yap (2001) found that there is a long run relationship between labour productivity and wages. On application of the Granger causality it was found that there is no causality between labour productivity and remuneration in South Africa and vice versa.

\section{References}

Akerlof, G. A. (1982), Labour contracts as partial gift exchanges, Quarterly Journal of Economics, 97, 543-569.

Akerlof, G. A. (1984), Gift exchange and efficiency-wage theory: four views, American Economic Review, 74, 2, 79-83.

Akerlof, G. A. \& Yellen, J. (1990), The fair wage-effort hypothesis and unemployment, Quarterly Journal of Economics, 105, 2, 255-283.

Alexander, C. O. (1993), The changing relationship between productivity, wages and unemployment in the UK, Oxford Bulletin of Economics and Statistics, 55, 87-102.

Banerjee, A., Dolado, J. J., Galbraith, J.W. \& Hendry, D. F. (1993), Cointegration, Error-correction, and the Econometric Analysis of Non-stationary Data. Oxford: Oxford University Press.

Barker, F. S. (2002), The South African Labour Market. $4^{\text {th }}$ Edition. Pretoria: J.L. van Schaik.

Bender, K. \& Theodossiou, I. (1999), International comparisons of the real wage-employment relationship, Journal of Post Keynesian Economics, 21, 4, 621-637.

Brown, C.V., Levin, E. \& Ulph, D.T. (1976), Estimates of labour hours supplied by married male workers in Great Britain, Scottish Journal of Political Economy, 23, 3, 261-677.

Dickey, D. A \& Fuller, W. A. (1979), Distributions of the Estimators for Autoregressive Time Series with a Unit Root, Journal of American Statistical Association, 74, 427-481.

Dickey, D. A. \& Fuller, W. A. (1981), Likelihood Ratio Statistics for Autoregressive Time Series With a Unit Root, Econometrica, 49, 1057-1072.

Du Plooy, R. M. (1988), Productivity in South African Industry. South African Journal of Economics.

Du Toit, C \& Koekemoer, R, (2003), A labour model for South Africa. South African Journal of Economics, 71, 1, $49-76$.

Erenburg, S. J. (1998), Productivity, private and public capital and real wage in the US, Applied Economics Letters, 5, 491-495.

Fedderke, J. W \& Mariotti, M. (2002), Changing labour market conditions in South Africa: A sectoral analysis for the period 1970-1997. South African Journal of Economics.

Gneezy, U. \& Rustichini, A. (2000), Pay enough or don't pay at all, Quarterly Journal of Economics, 115, 3, 791-810.

Goh, S. K. (2009), Is Productivity Linked To Wages? An Empirical Investigation in Malaysia, Centre of Policy Research \& International Studies, University Sains Malaysia (USM), Penang, Malaysia, MPRA Paper No. 18095.

Hall S. G. (1986), An application of the Granger and Engle two-step estimation procedure to United Kingdom aggregate wage data, 
Oxford Bulletin of Economics and Statistics, 48, 229- 239.

Ho, L. P. \& Yap, S. F. (2001), The link between wages and labour productivity: An analysis of the Malaysian manufacturing industry, Malaysian Journal of Economic Studies, 38, 1-2, 51-57.

Hondroyiannis, G. \& Papapetrou, E. (1997), Seasonality-cointegration and the inflation, productivity and wage growth relationship in Greece, Social Science Journal, 34,2, 235-247.

Johansen, S. (1988), Statistical analysis of cointegration vectors" Journal of Economic Dynamics and Control, 12, $231-254$.

Johansen, S. (1991), Estimation and hypothesis testing of cointegration vectors in Gaussian vector autoregressive models. Econometrica 59, 1551-1580.

MacKinnon, J.G. (1991), Critical value for cointegration tests, In R.F. Engle \& C.W.J. Granger (Eds.), Long run economic relationships: Reading in cointegration (pp. 267-276). Oxford University Press.

Maddala, G. S. \& Kim, I. M, (1998), Unit roots, cointegration, and structural change. Cambridge: Cambridge University Press.

Millea, M. (2002), Disentangling the Wage-Productivity Relationship: Evidence from Select OECD Member Countries, International Advances in Economic Research, 8, 314-323.

Nelson, C. R. \& Plosser, C. I. (1982), Trends and Random Walks in Macroeconomic Time Series: Some Evidence and Implications, Journal of Monetary Economics, 10, 139-162.

Phillips, P. C. B. \& Perron, P. (1988), Testing for a unit root in time series regression. Biometrika, 75, 335-346.

South African Reserve Bank (SARB). (2013), Yearly Bulletin, March. Pretoria: SARB.

Strauss, J. \& Wohar, M. E. (2004), The linkage between prices, wages and labour productivity: A panel study of manufacturing industries, Southern Economic Journal, 70, 920-941.

Wakeford, J. J. (2004), The productivity-wage relationship in South Africa: an empirical investigation. Development Southern Africa, 21, 1, 109-132.

www.statssa.gov.za

www.worldbank.org 
ISSN 2239-978X

ISSN 2240-0524
Journal of Educational and Social Research MCSER Publishing, Rome-Italy
Vol. 4 No. 6 September 2014 